\title{
DEMOGRAPHIC PARAMETERS OF BLACK APHID IN COWPEA CULTIVARS
}

\author{
Leandro Carvalho da Silva ${ }^{1}$, Daniel Rodrigues Nere ${ }^{1}$, Ervino Bleicher ${ }^{1}$, Antonio Vinícius Correa Barbosa ${ }^{2}$, Eraldo \\ José Madureira Tavares ${ }^{3}$
}

\author{
${ }^{1}$ Universidade Federal do Ceará, Avenida Mister Hull, s/n ${ }^{\circ}$ CEP 60455760 Fortaleza, CE. \\ ${ }^{2}$ Universidade Federal Rural da Amazônia, Avenida Perimetral, n² 2501, CEP 66077-830 Belém, PA. \\ ${ }^{3}$ Embrapa Amazônia Oriental, Travessa Doutor Enéas Pinheiro, s/n, CEP 66095-903, Belém, PA.
}

*Author for correspondence: Leandro Carvalho da Silva. I.carvalho22@hotmail.com

\begin{abstract}
The survival and development of Aphis craccivora Koch, 1854 (Hemiptera: Aphididae) can be affected by the characteristics of the different cowpea genotypes. The aim of this study was to estimate the demographic parameters of black aphid (Aphis craccivora Koch) in cowpea cultivars (Vigna unguiculata (L.) Walp.) of economic importance for Brazil. BRS Pingo de Ouro, BRS Tumucumaque, BRS Itaim, BRS Nova Era, BRS Imponente and BRS Guariba cultivars were used. VITA 7 cultivar participated in the study as an insect susceptibility standard. A cohort was formed, where each cultivar had 10 plants as replicates, and each replicate received an aphid. The number of live individuals, the number of offspring, which were later removed and the longevity of the cohort insects were daily recorded. The finite growth rate $(\lambda)$ can be considered as the indicator parameter of outbreak risk for this pest if its values are above 1.2. BRS Nova Era, BRS Imponente, BRS Tumucumaque, VITA 7, BRS Itaim, BRS Pingo de Ouro and BRS Guariba cultivars presented $\lambda$ values of 1.77, 1.74, 1.73, 1.73, 1.73, 1.71 and 1.16, respectively. For presenting survival on the occasion of the first offspring and gross reproduction rate (GRR), net reproduction rate $\left(R_{0}\right), R_{0}$ / GRR ratio, intrinsic growth rate $\left(r_{m}\right)$ and finite growth rate $(\lambda)$ values much lower than the others, BRS Guariba cultivar is suggested to have antibiosis type resistance.
\end{abstract}

KEYWORDS: Aphis craccivora, plant resistance, Vigna unguiculata.

\section{PARÂMETROS DEMOGRÁFICOS DO PULGÃO-PRETO EM CULTIVARES DE FEIJÃO-CAUPI}

RESUMO: A sobrevivência e o desenvolvimento de Aphis craccivora Koch, 1854 (Hemiptera: Aphididae) pode ser afetado pelas características dos diferentes genótipos de feijão-caupi. Objetivou-se estimar os parâmetros demográficos do pulgão-preto (Aphis craccivora Koch) em cultivares de feijão-caupi (Vigna unguiculata (L.) Walp.) de importância econômica para o Brasil. Foram usadas as cultivares: BRS Pingo de Ouro, BRS Tumucumaque, BRS Itaim, BRS Nova Era, BRS Imponente e BRS Guariba. A cultivar VITA 7 fez parte do estudo na qualidade de padrão de susceptibilidade ao inseto. Foi formado uma coorte, onde cada cultivar teve 10 plantas como réplicas, e cada réplica recebeu um pulgão. Foram registrados diariamente o número de indivíduos vivos, o número de descendentes, os quais em seguida foram retirados e a longevidade dos insetos da coorte. A razão finita de crescimento $(\lambda)$ pode ser considerada o parâmetro indicador de risco de surto para esta praga se seus valores estiverem acima de 1.2. Observou-se para as cultivares BRS Nova Era, BRS Imponente, BRS Tumucumaque, VITA 7, BRS Itaim, BRS Pingo de Ouro e BRS Guariba apresentaram os valores da $\lambda$ de 1.77, 1.74, 1.73, 1.73, 1.73, 1.71 e 1.16, respectivamente. A cultivar BRS Guariba por apresentar sobrevivência por ocasião do primeiro descendente, taxa bruta de reprodução (TBR), taxa líquida de reprodução $\left(R_{0}\right)$, relação entre $R_{0} / T B R$, taxa intrínseca de crescimento $\left(r_{m}\right)$ e razão finita de crescimento $(\lambda)$ muito inferior aos demais, sugere a resistência do tipo antibiose.

PALAVRAS-CHAVE: Aphis craccivora, resistência de plantas, Vigna unguiculata.

\section{INTRODUCTION}

Black aphid Aphis craccivora Koch, 1854 (Hemiptera: Aphididae) is considered one of the main pests of cowpea. This aphid has rapid development. At $25+2^{\circ} \mathrm{C}$, according to Valente et al. (2014), the four nymphal stages last 3.6 days in VITA 7 cultivar, which makes its control difficult (Akca et al., 2015). These insects can cause direct damage because, when 
feeding, they suck the sap of terminal shoots, petioles, flowers and pods of the host plant, which ends up by modifying their metabolism, as well as indirect, serving as vectors for the transmission of many viruses, such as the Cowpea Aphis borne mosaic virus, CABMV, the Cucumber mosaic virus, CMV and Cowpea severe mosaic virus, CPSMV (Asiwe, 2009; Ojuederie et al., 2009; Oliveira et al., 2012).

Traditionally, cowpea is planted in the Northeastern region of Brazil, and also used by small family farmers in the Amazon region. However, from the year 2006, the cultivation of cowpea in the Midwestern region of Brazil, mainly in the state of Mato Grosso, has been expanding because it is considered as a good option to be planted between soybean harvests, as main culture presents low production cost and excellent perspective in the international market. This development of the culture in the region is due to the breeding program of Embrapa Meio Norte, which has launched highly productive cultivars and with architecture that allows increasing the number of plants per hectare and the mechanization process of crops, such as erect and semi-erect cultivars (Freire Filho et al., 2011).

In all producing regions mentioned above, the black aphid is a limiting factor for cowpea cultivation, which contributes to a decrease in production, as well as an increase in costs. In the absence of control, high levels of infestation tend to cause a further loss of $50 \%$ of crop yield (Obopile, 2006). The chemical control method is still the most used, with the use of systemic insecticides, but its use causes several problems, such as the selection of resistant populations, causing losses to farmers and damage to the environment (Silva and Bleicher, 2010).

Thus, it is of great importance to know the demographic parameters of the black aphid, which is estimated from the elaboration of fertility life tables on the main cowpea cultivars planted in Brazil. The data of these tables allows predicting survival rates, as well as the development and breeding potential of the insect (Soroushmehr et al., 2008; Akca et al., 2015).

With the knowledge of such demographic parameters, it is possible to identify resistant and I or susceptible cultivars; those that in favorable environments can present pest outbreaks and assisting in the elaboration of a management plan for the cultivar chosen. Therefore, this research aims to estimate the demographic parameters of black aphid (Aphis craccivora Koch) in cowpea (Vigna unguiculata (L.) Walp.) cultivars of economic importance for Brazil.

\section{MATERIAL AND METHODS}

The work, with cultivars intended for mechanical harvesting, was carried out in the second semester of 2016 at the Agricultural Sciences Center (CCA), Campus do Pici, Federal University of Ceará-UFC, Fortaleza, CE, Brazil ( $3^{\circ} 40^{\prime} 24^{\prime \prime}$ S and $38^{\circ} 34^{\prime} 32^{\prime \prime} \mathrm{W}$, and $12 \mathrm{~m}$ a.s.l.), screen house covered on the sides with anti-aphid screen, and at the top with 200 micron plastic.

BRS Pingo de Ouro (local cultivar), BRS Tumucumaque (TE96-282-22G x IT87D-611-3), BRS Itaim (MNC01-625E-10-1-2-5 x MNC99-544D-10- 1-22), BRS Nova Era (TE97-404-1F x TE97 404-3F), BRS Imponente (MNCO0-553D-8-1-2-3 x MNC01626F-11-1), BRS Guariba (IT85F-2687 x TE87-98-8G) cultivars were used, as well as VITA 7 cultivar (TVx 28946 backcrossing) as a susceptibility pattern (Freire Filho et al., 2011; Cruz et al., 2012). The main characteristics of each cultivar are described in table 1.

Table 1. Characteristics of cultivars under dry farming system evaluated in the experiment

\begin{tabular}{lcccccc}
\hline Cultivar & $\begin{array}{c}\text { Commercial } \\
\text { sub-class }\end{array}$ & Size & Yield $\left(\mathrm{Kg} \mathrm{ha}^{-1}\right)$ & $\begin{array}{c}\text { Weight of 100 } \\
\text { seeds }(\mathrm{g})\end{array}$ & $\begin{array}{c}\text { Flowering } \\
\text { (days) }\end{array}$ & References \\
\hline VITA 7 & Branca & Semi-erect & 843 & 19.5 & $38-40$ & Freire Filho et al. 1983 \\
BRS Guariba & Branca & Semi-erect & 1.508 & 19.5 & 41 & Freire Filho et al. 2004 \\
BRS Itaim & Branca & Erect & 1.618 & 23 & 35 & Freire Filho et al. 2009 \\
BRS Tumucumaque & Branca & Semi-erect & 1.098 & 19.5 & 37 & Cavalcante et al. 2014 \\
BRS Nova Era & Brancão & Semi-erect & $1.074,3$ & 20 & 41 & Freire Filho et al. 2008 \\
BRS Imponente & Branca & Semi-erect & 2.181 & 34 & - & Embrapa, 2016 \\
BRS Pingo de Ouro & Canapu & Prostrated & $1.098,59$ & 19.05 & 45.25 & Gonçalves et al. 2009 \\
\hline
\end{tabular}


In order to ensure that the insects used in the experiment belonged to the same generation and age, the age standardization of aphid colonies was performed. For this, ten VITA 7 cultivar seeds were planted in $2.8 \mathrm{~L}$ pots using sand, humus and vermiculite as substrate at proportion of $6: 3: 1$. After the fifth day of planting, pruning was performed, leaving five plants per pot, and on the eleventh day after planting, infestation was carried out with five aphids per plant. The aphids used in the infestation were female, adult, wingless, rounded in shape and bright black color. After 24 hours of infestation, adult insects were removed with the aid of a brush, keeping only the nymphs produced. On the sixth day after infestation, adult aphids of the same age were transferred to the leaves of cultivars to be evaluated.

Cultivars were sown in $300 \mathrm{~mL}$ pots with three holes at the base, which were filled with the same substrate used in the age standardization. Two seeds were sown per pot, and on the fifth day, punning was performed, leaving only one plant per pot. Plants were irrigated daily, once a day, and after infestation, they began to be irrigated twice a day until the end of the experiment in order to avoid possible stresses to plants, which could lead to a possible alteration of results.

The infestation of cultivars was carried out on the twelfth day after sowing, depositing 5 adult aphids per plant from the colonies of age standardization, in the first hours of the day. Then, already infested plants were arranged in benches without touching, and covered with cages coated with anti-aphid screen of $1.0 \mathrm{~m}$ in width, $1.0 \mathrm{~m}$ in length and $0.50 \mathrm{~m}$ in height.

Due to parturitions, adult insects were removed about 4 hours after infestation, remaining only 2 nymphs per plant within 24 hours. After this period, a cohort of 10 individuals was formed, and distributed in 10 replicates of the cultivar, one aphid per plant. The same was performed in the 7 cultivars. The number of living individuals; the number of descendants, which were then removed; and the longevity of cohort insects were daily recorded. The experiment consisted of seven treatments, with ten replicates.

With information regarding the daily number of offspring and survival in each age group, fertility life tables of $A$. craccivora were elaborated for each
V. unguiculata cultivar. From these, the following were evaluated: survival at production of the first offspring ( $\left.S 1^{\text {st }} \mathrm{O}\right)$, which indicates the chances of nymphs reaching adulthood and procreating; the $R_{0} / G R R$ ratio, where values closer to 1.0 means that there is higher degree of adaptation of the genotype as food to the insect; and the gross reproduction rate (GRR) (Hoque et al., 2008), which represents the total mean number of nymphs produced per female over its useful life. The demographic parameters of the black aphid were estimated using the Jackknife method, according to routine presented by Maia et al. (2000), using the statistical package (SAS Institute, 2002), at 5\% probability level. The net reproduction rate $\left(R_{0}\right)$; average interval between generations ( $T$ ); time to double the population $\left(\mathrm{T}_{\mathrm{D}}\right)$; intrinsic growth rate $\left(r_{m}\right)$ and finite growth rate $(\lambda)$ were estimated.

After the results of the evaluated parameters, the averages were ranked according to methodology proposed by Mulamba and Mock (1978), where the lowest score was attributed to the average of greatest interest in the research, in order of resistance. With the ranking data corresponding to the evaluated parameters, they were summed in order of each genotype and, consequently, originating the sum of posts $(\Sigma p)$, which represents the joint action of the genotype on the population parameters of the insect.

\section{RESULTS AND DISCUSSION}

When observing survival at production of the first offspring ( $\left.S 1^{\text {st }} O\right)$ on the cultivars studied, it was verified that the level of mortality in the nymphal phase was very high on insects that fed on the BRS Guariba cultivar, where only $20 \%$ of individuals reached the adult stage and procreated, while in the other cultivars ( $S 1^{\text {st }} \mathrm{O}$ ), it ranged from 90 to $100 \%$ (Table 2). The low survival rate of aphids in the nymphal phase on BRS Guariba is indicative of antibiosis, suggesting a plant defense mechanism. Paz (2016) attributed antibiosis resistance to the high mortality rate of $A$. craccivora still in the nymphal phase on the BRS Guariba cultivar. 
Table 2. Demographic parameters: Survival at production of the first offspring ( $\left.S 1^{\text {st }} \mathrm{O}\right)$, gross reproduction rate (GRR), net reproduction rate $\left(R_{0}\right), R_{0} / G R R$ ratio, mean interval between generations $\left(r_{m}\right)$, finite growth rate $(\lambda)$, and sum of posts $\left(\sum p\right)$ of Aphis craccivora in cowpea cultivars.

\begin{tabular}{|c|c|c|c|c|c|c|c|c|c|c|c|c|c|c|c|c|c|}
\hline \multirow{2}{*}{ Cultivars ${ }^{(1)}$} & \multicolumn{17}{|c|}{ Demographic parameters } \\
\hline & $\mathrm{S} 1^{\text {st }} \mathrm{O}(\%)$ & $P^{(2)}$ & GRR & $P$ & $\mathrm{R}_{0}$ & $P$. & $\mathrm{R}_{\mathrm{o}} / \mathrm{GRR}$ & $P$. & $\mathrm{T}$ & $P$ & $\mathrm{~T}_{\mathrm{D}}$ & P. & $r_{m}$ & P. & $\lambda$ & $P$. & $\sum p$ \\
\hline VITA7 & 100 & 3 & 87.20 & 5 & $\begin{array}{c}65.2 \mathrm{a} \\
(42.2-88.2)\end{array}$ & 7 & 0.75 & 7 & $\begin{array}{c}7.5 a \\
(6.99-8.16)\end{array}$ & 2 & $\begin{array}{c}1.25 b \\
(1.17-1.33)\end{array}$ & 3 & $\begin{array}{c}0.55 a \\
(0.52-0.59)\end{array}$ & 3 & $\begin{array}{c}1.73 a \\
(1.68-1.79)\end{array}$ & 3 & $33.00^{(3)}$ \\
\hline $\begin{array}{l}\text { BRS } \\
\text { Pingo de Ouro }\end{array}$ & 90 & 2 & 89.80 & 7 & $\begin{array}{c}55.8 \mathrm{a} \\
(37.4-74.2)\end{array}$ & 4 & 0.62 & 2 & $\begin{array}{c}7.5 a \\
(6.81-8.21)\end{array}$ & 2 & $\begin{array}{c}1.29 b \\
(1.21-1.37)\end{array}$ & 2 & $\begin{array}{c}0.53 \mathrm{a} \\
(0.50-0.57)\end{array}$ & 2 & $\begin{array}{c}1.71 \mathrm{a} \\
(1.65-1.77)\end{array}$ & 2 & 23.00 \\
\hline $\begin{array}{l}\text { BRS } \\
\text { Tumucumaque }\end{array}$ & 100 & 3 & 83.03 & 4 & $\begin{array}{c}60.6 \mathrm{a} \\
(38.6-82.6)\end{array}$ & 5 & 0.73 & 6 & $\begin{array}{c}7.4 \mathrm{a} \\
(7.10-7.84)\end{array}$ & 3 & $\begin{array}{c}1.25 \mathrm{~b} \\
(1.18-1.33)\end{array}$ & 3 & $\begin{array}{c}0.55 \mathrm{a} \\
(0.52-0.58)\end{array}$ & 3 & $\begin{array}{c}1.73 a \\
(1.67-1.79)\end{array}$ & 3 & 30.00 \\
\hline $\begin{array}{l}\text { BRS } \\
\text { Itaim }\end{array}$ & 100 & 3 & 69.19 & 3 & $\begin{array}{c}47.5 \mathrm{a} \\
(28.2-66.8)\end{array}$ & 3 & 0.69 & 4 & $\begin{array}{c}7.0 \mathrm{a} \\
(6.42-7.62)\end{array}$ & 5 & $\begin{array}{c}1.25 b \\
(1.19-1.31)\end{array}$ & 3 & $\begin{array}{c}0.55 \mathrm{a} \\
(0.53-0.58)\end{array}$ & 3 & $\begin{array}{c}1.73 a \\
(1.69-1.78)\end{array}$ & 3 & 27.00 \\
\hline $\begin{array}{l}\text { BRS } \\
\text { Nova Era }\end{array}$ & 100 & 3 & 89.16 & 6 & $\begin{array}{c}62.3 \mathrm{a} \\
(41.0-83.6)\end{array}$ & 6 & 0.70 & 5 & $\begin{array}{c}7.2 a \\
(6.60-7.79)\end{array}$ & 4 & $\begin{array}{c}1.20 \mathrm{~b} \\
(1.13-1.27)\end{array}$ & 5 & $\begin{array}{c}0.57 \mathrm{a} \\
(0.54-0.61)\end{array}$ & 4 & $\begin{array}{c}1.77 \mathrm{a} \\
(1.71-1.84)\end{array}$ & 5 & 38.00 \\
\hline $\begin{array}{l}\text { BRS } \\
\text { Imponente }\end{array}$ & 90 & 2 & 53.42 & 2 & $\begin{array}{c}34 \mathrm{a} \\
(17.9-50.1)\end{array}$ & 2 & 0.63 & 3 & $\begin{array}{c}6.3 a \\
(5.92-6.85)\end{array}$ & 6 & $\begin{array}{c}1.24 b \\
(1.11-1.38)\end{array}$ & 4 & $\begin{array}{c}0.55 \mathrm{a} \\
(0.49-0.61)\end{array}$ & 3 & $\begin{array}{c}1.74 \mathrm{a} \\
(1.64-1.84)\end{array}$ & 4 & 26.00 \\
\hline $\begin{array}{l}\text { BRS } \\
\text { Guariba }\end{array}$ & 20 & 1 & 21.50 & 1 & $\begin{array}{c}4.2 \mathrm{~b} \\
(-0.88-9.28)\end{array}$ & 1 & 0.19 & 1 & $\begin{array}{c}9.4 a \\
(-3.57-22.4)\end{array}$ & 1 & $\begin{array}{c}4.55 a \\
(2.04-7.07)\end{array}$ & 1 & $\begin{array}{c}0.15 b \\
(0.06-0.24)\end{array}$ & 1 & $\begin{array}{c}1.16 b \\
(1.06-1.26)\end{array}$ & 1 & 8.00 \\
\hline
\end{tabular}

(1) Confidence interval at 95\% probability. Means followed by the same letter in the column do not differ from each other by means of two-to-two treatment comparisons through the $95 \%$ probability confidence interval after error estimation by the Jackknife method (SAS Institute, 2002) using the t test. (2) Occupied post for the observed variable. (3) The lower the sum of posts, the more promising are cultivars for resistance, when taking into consideration the eight evaluated parameters.

In the present study, the gross reproduction rate (GRR) ranged from 21.50 to 89.16 nymphs produced. BRS Nova Era and VITA 7 cultivars presented the highest GRR (89.16 and 87.20), while BRS Guariba, the smallest (21.50) (Table 2). Low gross reproduction rates demonstrate the negative effects of hosts on the number of offspring produced on average per female. For some authors, nutrition and the presence of compounds with antibiotic characteristics directly affect fecundity, causing a decrease in the reproductive capacity of the insect (Panizzi and Parra, 2009; La Rossa et al., 2013).

The net reproduction rate $\left(R_{0}\right)$ values were higher when insects fed on VITA 7 (65.2), BRS Nova Era (62.3), BRS Tumucumaque (60.6), BRS Pingo de Ouro (55.8), BRS Itaim (47.5) and BRS Imponente (34.0) cultivars, which significantly differed $(P<0.05)$ from BRS Guariba cultivar, with lower $R_{0}$ value (4.2) (Table 2). This shows that the aphid, when feeding on the BRS Guariba cultivar, suffers a reduction in the capacity to increase the population, making the cultivar inadequate as host for the insect. Soffan and Aldawoord (2014) describe the Misr1 cultivar (Vicia faba) as suitable for the development of $A$. craccivora when evaluating the whole plant, presenting a net reproduction rate value of
58.31, which is much lower than that found in present study for VITA 7 cultivar, the susceptibility pattern.

Plants with net reproduction rate $\left(R_{0}\right)$ above 40 present optimum conditions for the development of Aphis gossypii Glover, 1877 (Hemiptera: Aphididae) (Takallozadeh, 2010). This indicates that, even among aphids of different species, but belonging to the same genus, individuals with $\mathrm{RO}$ greater than 34 when fed on cowpea cultivars tend to be fully developed and do not find resistance to increase their populations, as verified in this research.

Regarding the $\mathrm{R}_{0}$ / GRR ratio, BRS Guariba cultivar presented lower preference (0.19), while VITA 7 and BRS Tumucumaque cultivars were the most preferred (0.75 and 0.73 ) (Table 2). According to Aoyama and Labinas (2012), the presence of secondary compounds interferes in the feeding preference of the insect by the host.

Regarding the interval between generations $(T)$, no significant differences were observed among treatments $(P<0.05)$ (Table 2$)$. In this case, none of the cultivars used were able to affect the $T$ value of the black aphid, where the average period of one generation of $A$. craccivora varies from 6 to 9 days (Machacha et al., 
2012). As for the time to double the population $\left(T_{D}\right), B R S$ Guariba treatment significantly differed $(P<0.05)$ from the others, for which the black aphid presented higher $T_{D}$ (4.55 days), that is, in practical field conditions, it would take this time to double its population in number, unlike BRS Nova Era treatment, which would take only 1.20 days, thus demonstrating the susceptibility of the cultivar to the pest (Table 2).

The intrinsic growth rate $\left(r_{m}\right)$ and finite growth rate values $(\lambda)$ in A. craccivora on BRS Guariba were significantly different $(P<0.05)$ than those obtained in other cowpea cultivars. The $r_{\mathrm{m}}$ value ranged from 0.15 to 0.57 , and $\lambda$ value from 1.16 to 1.77 . The lowest $r_{\mathrm{m}}$ and $\lambda$ values were reached in the BRS Guariba group, and the highest values in the BRS Nova Era group (Table 2).

In this study, all cultivars tested, except for BRS Guariba, behaved as hosts suitable for A. craccivora, reaching high intrinsic growth rate values between 0.53 and 0.57 , compared to 0.16 of the BRS Guariba cultivar.

Aliyu and Ishiyaku (2013) investigated the identification of new sources of genes resistant to black aphid in cowpea and found that IT90K-76 and Saka Babba Sata genotypes presented high antibiosis level on the black aphid development, with intrinsic growth rate of 0.117 and 0.148 , respectively. These values are very similar to those found in this research on the BRS Guariba cultivar, thus demonstrating its resistance and ability to affect the reproductive potential of $A$. craccivora.

Obopile and Ositile (2010) and Machacha et al. (2012) obtained intrinsic growth rate values $(0.13$ and 0.22 ) close to those found in this study, demonstrating that the genotypes that showed to be resistant to black aphid were able to negatively affect the reproduction of A. craccivora and, consequently, several demographic parameters. Jalalipour et al. (2017) evaluated the demographic parameters of $A$. craccivora on Robinia pseudoacacia Físia under laboratory and field conditions and obtained $r_{m}$ values of 0.2339 and 0.1906 , and $\lambda$ values of 1.2635 and 1.2100 .

The nutritional quality and specific metabolic types of each cowpea cultivar were possibly important factors for direct interference on the demographic parameters evaluated, causing a positive or negative effect on insect biology, directly reflecting on fecundity, survival and population development (Asiwe, 2009, Panizzi and Parra, 2009).
The low net reproduction rate and survival of the first descendant of $A$. craccivora when developed on BRS Guariba cultivar resulted in low reproductive performance, which was reflected in the low intrinsic growth rate and, consequently, in the lowest finite growth ratio. Thus, BRS Guariba cultivar can be considered, among the 7 cultivars evaluated, less suitable for the black aphid development.

However, one must be aware of the danger in the use of resistant cultivars due to the selection pressure, which may lead to the emergence of new resistant biotypes, since insects that survived on BRS Guariba cultivar could, throughout their generations, transmit to their progeny the gene that confers resistance to the antibiotic compound (Dogimont et al., 2010; Souleymane et al., 2013).

When evaluating the joint action of cultivars on the population and biological parameters of the insect, by means of a sum of posts ( $\left.\sum p\right)$ (Table 2 ), it was verified that BRS Guariba cultivar presented a smaller sum of posts, showing the most promising among cultivars evaluated due to the resistance to black aphid. This result is a confirmation of the resistance of BRS Guariba cultivar because it caused a reduction in reproductive potential and survival, which directly influenced the results of each evaluated parameter.

Currently in the main growing state, Mato Grosso, the BRS Tumucumaque cultivar is the most planted followed by BRS Nova Era. In 2016, Embrapa launched a new cultivar BRS Imponente, a genotype that promises to exceed the expectations of producers and consumers, with features that meet the international market (Santos, 2015). When comparing the results between recently introduced BRS Imponente cultivar and the others in use, with the exception of BRS Guariba, it is potentially more susceptible to presenting pest outbreaks, given the favorable environmental conditions.

The BRS Imponente cultivar shows a tendency of high productivity in relation to the other cultivars (Table 1). But this should not be the sole criterion for the choice of the variety. Semi-erect and erect cultivars are recommended for mechanized harvesting. On the other hand, if the choice is to take into account regions favorable or not to aphid outbreaks, the choice is for BRS Guariba in areas subject to aphids and BRS Imponente in those where the occurrence is sporadic. These considerations do not take into account consumer 
preference, which will ultimately define the cultivar to be planted.

According to Razmjou et al. (2009), the use of resistant varieties or cultivars with low level of population growth is an important tool in Integrated Pest Management (IPM). Thus, it could be concluded that the BRS Guariba cultivar significantly contributes to the decrease of the reproductive potential and development of $A$. craccivora, presenting antibiosis resistance, and with the exception of BRS Guariba, all other cultivars evaluated are suitable for the development of this pest, taking into account the set of demographic estimates studied. This research also points out to the need to evaluate the resistance to aphids in advanced strains and thus avoid the release of cultivars more susceptible than those in use by producers

\section{ACKNOWLEDGMENTS}

To the National Council for Scientific and Technological Development (CNPq) for the resources assigned to carry out this research.

\section{REFERENCES}

Akca, I.; Ayvaz, T.; Yazici, E.; Smith, C.L.; Chi, H. Demography and Population Projection of Aphis fabae (Hemiptera: Aphididae): with Additional Comments on Life Table Research Criteria. Journal of Economic Entomology, 2015, 108, 4, 1466-1478. https://doi. org/10.1093/jee/tov187.

Aliyu, H.; Ishiyaku, M.F. Identification of novel resistance gene sources to cowpea aphid (Aphis craccivora Koch) in cowpea (Vigna unguiculata L.). Pakistan Journal of Biological Sciences, 2013, 16, 17, 743-746. https://doi. org/10.3923/pjbs.2013.743.746.

Aoyama, E.M.; Labinas, A.M. Características estruturais das plantas contra a herbivoria por insetos. Enciclopédia Biosfera, 2012, 8, 15, 365-386. http:// www.conhecer.org.br/enciclop/2012b/ciencias $\% 20$ agrarias/caracteristicas\%20estruturais.pdf.

Asiwe, J.A.N. The impact of phosphate fertilizer as a pest management tactic in four cowpea varieties. African Journal Biotechnology, 2009, 24, 8, 7182-7186. https://www.ajol.info/index.php/ajb/article/view/68820.
Cavalcante, S.C.; Freire Filho, F.R.; Rocha, M.M.; Ribeiro, V.Q.; Damasceno e Silva, K.J. BRS Tumucumaque: Cultivar de Feijão-Caupi para o Amapá e Outros Estados do Brasil. Macapá, 2014. http://ainfo. cnptia.embrapa.br/digital/bitstream/item/122943/1/ CPAF-AP-2014-CT-124-BRSTumucumaque.pdf.

Cruz, P.L.; Baldin, E.L.L.; Castro, M.J.P.; Fanela, T.L.M.; Silva, P.H.S. Atratividade de genótipos de feijão-caupi para oviposição de Bemisia tabaci biótipo B. Pesquisa Agropecuária Brasileira, 2012, 47, 11, 1563-1571. https://seer.sct.embrapa.br/index.php/pab/article/ view/12673/8224.

Dogimont, C.; Bendahmane, A.; Chovelon, V.; Boissot, N. Host plant resistance to aphids in cultivated crops: Genetic and molecular bases, and interactions with aphid populations. Comptes Rendus Biologies, 2010, 333, 566-573. https://doi.org/10.1016/j.crvi.2010.04.003.

Embrapa. BRS Imponente: cultivo precoce e mecanizado e grãos extra grandes são os diferencias da cultivar. 2016. https://www.embrapa.br/en/busca-depublicacoes/-/publicacao/1047743/brs-imponente.

Freire Filho, F.R.; Rocha, M.M.; Ribeiro, V.Q.; Damasceno e Silva, K.J.; Carvalho, H.W.L.; Cravo, M.S.; Lopes, A.M.; Vilarinho, A.A.; Saboya, R.C.; Cavalcante, E.S.; Costa, A.F.; Alcântara, J.P.; Sittolin, I.M. BRS Itaim: cultivar de feijão-caupi com grãos tipo fradinho. Teresina - Piauí, 2009. https://ainfo.cnptia.embrapa.br/ digital/bitstream/item/80763/1/brs-itaim.pdf.

Freire Filho, F.R.; Cravo, M.S.; Vilarinho, A.A.; Cavalcante, E.S.; Fernandes, J.B.; Sagrilo, E.; Ribeiro, V.Q.; Rocha, M.M.; Souza, F.F.; Lopes, A.M.; Gonçalves, J.R.P.; Carvalho, H.W.L.; Raposo, J.A.A.; Sampaio, L.S. BRS Nova Era: Cultivar de feijão-caupi de porte semi-ereto. Belém - Pará, 2008. https://www.embrapa.br/en/busca-de-publicacoes/-/ publicacao/408906/brs-novaera-cultivar-de-feijaocaupi-de-porte-semi-ereto.

Freire Filho, F.R.; Santos, A.A.; Araújo, A.G.; Cardoso, M.J.; Ribeiro, V.Q.; Santos, M.L.B.; Martins, R.P. VITA 3 e VITA - 7, cultivares de feijão macassar para o Piauí. Teresina - Piauí, 1983. https://www.infoteca.cnptia. embrapa.br/handle/doc/51642. 
Freire Filho, F.R.; Ribeiro, V.Q.; Rocha, M.M.; Damasceno e Silva, K.J.; Nogueira, M.S.R.; Rodrigues, E.V. Feijão-caupi no Brasil: produção, melhoramento genético, avanços e desafios. Teresina: Embrapa Meio-Norte, 84 p., 2011. https://www.embrapa.br/ busca-de-publicacoes/-/publicacao/916831/feijaocaupi-no-brasil-producao-melhoramento-geneticoavancos-e-desafios.

Freire Filho, F.R.; Ribeiro, V.Q.; Rocha, M.M.; Sillva, S.M.S.; Sittolin, I.M. BRS Guariba: Nova cultivar de feijão-caupi para a região Meio-Norte. Teresina - Piauí, 2004. https://www.infoteca.cnptia.embrapa.br/handle/ doc/54343.

Gonçalves, J.R.P.; Fontes, J.R.A.; Morais, R.R.; Diógenes, H.C.; Santos, P.A.; Silva, A.C.; Rocha, M.M.; Silva, K.J.D.; Freire Filho, F.R. Comportamento de genótipos semi-prostrados e prostrados de feijão-caupi em ecossistemas de várzea amazônica. In: Congresso Nacional de Feijão-Caupi, 2. Belém, PA. Da agricultura de subsistência ao agronegócio: Anais. Belém, PA: Embrapa Amazônia Oriental, 2009. p. 389-393. https:// www.alice.cnptia.embrapa.br/handle/doc/896494.

Hoque, M.F.; Islam, W.; Khalequzzaman, M. Life tables of two-spotted spider mite Tetranychus urticae Koch (Acari: Tetranychidae) and its predator Phytoseiulus persimilis athias-henriot (Acari: Phytoseiidae). Journal Biological Sciences, 2008, 16, 1-10. http://dx.doi. org/10.3329/jbs.v16i0.3733.

Jalalipour, R.; Sahragard, A.; Madahi, K.H.; KarimiMalati, A. Comparative life table of Aphis craccivora (Hem.: Aphididae) on host plant, Robinia pseudoacacia under natural and laboratory conditions. Journal of Entomological, 2017, 36, 4, 249-257. https://www. researchgate.net/publication/315619075.

La Rossa, F.R.; Vasicek, A.; López, M.C. Effects of pepper (Capsicum annuum) cultivars on the biology and life table parameters of Myzus persicae (Sulz.) (Hemiptera: Aphididae). Neotropical Entomology, 2013, 42, 6, 634-641. https://doi.org/10.1007/s13744-0130166-9.

Machacha, M.; Obopile, M.; Tshegofatso, A.B.N.; Tiroesele, B.; Gwafila, C.; Ramokapane, M. Demographic parameters of cowpea aphid Aphis craccivora (Homoptera: Aphididae) on different Botswana cowpea landraces. International Journal of Tropical Insect Science, 2012, 32, 4, 189-193. https:// doi.org/10.1017/S1742758412000318.

Maia, H.N.M.; Luiz, A.J.B.; Campanhola, C. Statistical Inference on associated fertility life table parameters using jackknife technique: computational aspects. Journal of Economic Entomology, 2000, 93, 2, 511-518. https://doi.org/10.1603/0022-0493-93.2.511.

Mulamba, N.N.; Mock, J.J. Improvement of yield potential of the Eto Blanco maize (Zea mays L.) population by breeding for plant traits. Egypt Journal of Genetics and Cytology, 1978, 7, 1, 40-51. http://www. bdpa. cnptia.embrapa.br/consulta/busca?b=ad\&id=396 755\&biblioteca=vazio\&busca=autoria: $\% 22 \mathrm{MOCK}, \% 20$ J.\%20J.\%22\&qFacets=autoria:\%22MOCK, \%20J.\%20 J.\%22\&sort=\&paginacao=t\&paginaAtual=1.

Obopile, M. Economic Threshold and Injury Levels for Control of Cowpea Aphid, Aphis craccivora L. (Homoptera: Aphididae) on Cowpea. African Plant Protection, 2006, 12, 111-115. https:// www.researchgate.net/publication/230807027.

Obopile, M.; Ositile, B. Life table and population parameters of cowpea aphid, Aphis craccivora Koch (Homoptera: Aphididae) on five cowpea Vigna unguiculata (L.) Walp. varieties. Journal of Pesticide Science, 2010, 83, 9-14. https://doi.org/10.1007/ s10340-009-0262-0.

Ojuederie, O.B.; Odu, B. O.; Ilori, C.O. Serological detection of seed borne viruses in cowpea regenerated germplasm using protein a sandwich enzyme linked immunorsorbent assay. African Crop Science Journal, 2009, 17, 3, 125-132. http://dx.doi.org/10.4314/acsj. v17i3.54212.

Oliveira, C.R.R.; Freire Filho, F.R.; Nogueira, M.S.R.; Barros, G.B.; Eiras, M.; Ribeiro, V.Q.; Lopes, C.A. Reação de genótipos de feijão-caupi revela resistência às infecções pelo Cucumber mosaic virus, Cowpea aphid-borne mosaic virus e Cowpea severe mosaic vírus. Bragantia, 2012, 71, 1, 59-66. http://ainfo. cnptia.embrapa.br/digital/bitstream/item/71072/1/ VirusMosaicoFeijaoCaupiFreire.pdf. 
Panizzi, A.R.; Parra, J.R.P. Bioecologia e nutrição de insetos - base para o manejo integrado de pragas. Embrapa, Brasília, Brasil, 2009, 1169 p.

Paz, J.K.S. Resistência de genótipos de Vigna unguiculata I. (Walp.) a Aphis craccivora Koch e seus aspectos biológicos e demográficos. Fortaleza, 81 p., Tese (Doutorado) - Universidade Federal do Ceará, 2016.

Razmjou, J.; Vorburger, A.; Tavakkoli, H.; Fallahi, A. Comparative population growth parameters of the twospotted spider mite, Tetranychus urticae Koch (Acari: Tetranychidae), on different common bean cultivars. Systematic Applied Acarology, 2009, 14, 2, 83-90.

Santos, G. B. Paralelo do plantio das cultivares de feijões caupi em Mato Grosso. Disponível em: <http:// grtrade.com.br/paralelo-do-plantio-das-cultivares-defeijoes-caupi-em-mt/>. 2015. Acesso em: 29 abril 2017.

SAS Institute. Getting started with the SAS learning edition. Cary: SAS Institure, 2002. 200p.

Silva, J.F.; Bleicher, E. Resistência de genótipos de feijão-de-corda ao pulgão-preto. Pesquisa Agropecuária Brasileira, 2010, 45, 10, 1089-1094. https://seer.sct. embrapa.br/index.php/pab/article/view/8232/6857.

Soffan, A.; Aldawood, A.S. Biology and demographic growth parameters of cowpea aphid (Aphis craccivora) on faba bean (Vicia faba) cultivars. Journal of Insect Science, 2014, 14, 120, 1-10. https://dx.doi. org/10.1673\%2F031.014.120.
Soroushmehr, Z.; Sahragard, A.; Salehi, L. Comparative life table statistics ladybeetle Scymnus syriacus reared on the green citrus aphid, Aphis spiraecola, fed on two host plants. Journal of Entomological Science, 2008, 11, 281-288. http://doi.org/10.1111/j.14798298.2008.00275.x.

Souleymane, A.; Aken'ova, M.E.; Fatokun, C.A.; Alabi, O.Y. Screening for resistance to cowpea aphid (Aphis craccivora Koch) in wild and cultivated cowpea (Vigna unguiculata L. Walp.) accessions. International Journal of Science, Environment and Technology, 2013, 2, 4, 611-621. http://hdl.handle.net/10568/76432.

Takallozadeh, M.J. Effects of host plants and various temperatures on population growth parameters of Aphis gossypi Glover (Hom: Aphididae). Middle East Journal of Cientific Research, 2010, 6, 1, 25-30. http://www. idosi.org/.../5.pdf.

Valente, E.C.N.; Trindade, R.C.P.: Broglio, S.M.F.; Duarte, A.G.; Rodrigues, V.M.; Lima, H.M.A.; Batista, N.S.; Santos, J.R. Aspectos biológicos de Aphis craccivora Koch (Hemiptera: Aphididae) em cultivares de feijão-caupi Vigna unguiculata (L.) Walp. Ciência Agrícola, 2014, 12, 1, 17-20. http://www. seer.ufal.br/index.php/revistacienciaagricola/article/ view/1072/1274. 